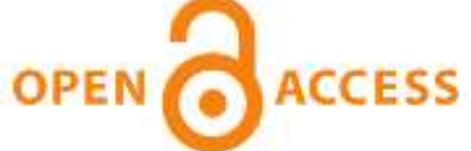

\section{International Journal of Applied Sciences and Biotechnology}

\section{A Rapid Publishing Journal}

ISSN 2091-2609

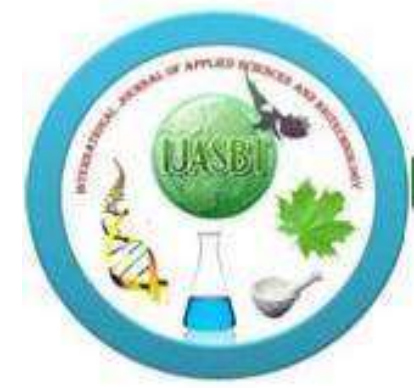

\section{Available online at:}

http://www.ijasbt.org

$\&$

http://www.nepjol.info/index.php/IJASBT/index

\section{Indexing and Abstracting}

CrossRef, Google Scholar, Global Impact Factor, Genamics, Index Copernicus, Directory of Open Access Journals, WorldCat, Electronic Journals Library (EZB), Universitätsbibliothek Leipzig, Hamburg University, UTS (University of Technology, Sydney): Library, International Society of Universal Research in Sciences (EyeSource), Journal Seeker, WZB, Socolar, BioRes, Indian Science, Jadoun Science, Jour-Informatics, Journal Directory, JournalTOCs, Academic Journals Database, Journal Quality Evaluation Report, PDOAJ, Science Central, Journal Impact Factor, NewJour, Open Science Directory, Directory of Research Journals Indexing, Open Access Library, International Impact Factor Services, SciSeek, Cabell's Directories, Scientific Indexing Services, CiteFactor, UniSA Library, InfoBase Index, Infomine, Getinfo, Open Academic Journals Index, HINARI, etc.

\section{CODEN (Chemical Abstract Services, USA): IJASKD}

Vol-2(4) December, 2014
Impact factor*: $\mathbf{1 . 4 2 2}$

Scientific Journal Impact factor": 3.419 Index Copernicus Value: $\mathbf{6 . 0 2}$

\section{SEM-Biotech}

Publishing

*Impact factor is issued by Universal Impact Factor. Kindly note that this is not the IF of Journal Citation Report (JCR). 


\title{
COMPARATIVE FORAGING BEHAVIOR OF APIS CERANA F. AND APIS MELLIFERA L. IN RAPESEED UNDER CAGE CONDITION IN CHITWAN, NEPAL
}

\author{
Rameshwor Pudasaini ${ }^{*}$ and Resham Bahadur Thapa ${ }^{2}$ \\ Institute of Agriculture and Animal Science, Rampur, Chitwan, Nepal \\ *Corresponding Author email: rameshwor.ent@gmail.com
}

\begin{abstract}
An experiment was conducted to determine the foraging behavior of Apis mellifera $\mathrm{L}$. and Apis cerana $\mathrm{F}$. in rapeseed under cage condition in Chitwan, Nepal during 2012-2013. This experiment showed that Apis cerana F. foraged extra 42 minute per day as compared to Apis mellifera L. Apis cerana F. were more attracted to nectar, whereas Apis mellifera $\mathrm{L}$. were more attracted to pollen collection throughout the day. The activities, in into hives and out from hives, for both species were recorded more at 2:00 pm and least at 8:00 am. The highest in-out were observed at 2:00 pm on both species as Apis mellifera L. 44.33 bees entered into hives and 49.66 bees went out of hives, whereas lower number of Apis cerana F. 43.66 bees entered into hives and 48.16 bees were out of hives. Apis mellifera $\mathrm{L}$. collect 1.22:1 and 0.41:1 pollen nectar ratio at 10:00 am and 4:00 am whereas at same hours Apis cerana collect 1.16:1 and 0.30:1 pollen nectar ratio. Apis cerana F. foraged significantly higher number of rapeseed flowers and plants as compared to Apis mellifera L. under caged condition. It shows that Apis cerana F. was more efficient pollinator as compared to Apis mellifera $\mathrm{L}$. under caged condition.
\end{abstract}

Key words: Apis mellifera L.; A. cerana F.; Cage plots; foraging efficiency

\section{Introduction}

The flowers of rapeseed, important sources for both pollen and nectar, are very attractive to honeybees. They are major pollinators of rapeseed (Brassica campestris L. var. toria) (Dhakal, 2003). Among the total pollination activities, over $80 \%$ is performed by insects and bees contribute nearly $80 \%$ of the total insect pollination and therefore, they are considered the best pollinators (Robinson and Morse, 1989). Bee pollination improves the yield and quality of crops, such as fruits, vegetable seeds, spices, oilseeds and forage crops (Partap and Partap, 1997; Dhakal, 2003; NARC, 2008).

The number of flowers visited per minute by any type of bee species depends upon the number of factors including instinctive foraging behaviour, length of proboscis (Inouye, 1980) floral structure (Free, 1970) particularly the corolla depth (Gilbert, 1980) type and quantity of floral rewards (Rao and Suryanarayana, 1990; Rao, 1991) density of flowers on particular cultivar of the crop concerned and hours of the day. Foraging behavior play an important role on the production and productivity of the crops which is use to compare pollination efficiency of different honeybee species. More foraging frequency indicated the more pollination efficiency (Singh et. al. 2006). The knowledge on bee behaviour and foraging activity and their interactions with different plant species are pre-requisite to frame on strategy for effective crop pollination. Similarly, initiation and cessation of foraging time help on determine the environmental effect on foraging behavior. Likewise, the number of bees per meter square in field gives the density of honeybee, availability of pollinators and their effect on crop production. Therefore, this study attempts to compare foraging activities of the Apis cerana $\mathrm{F}$. and Apis mellifera L. in rapeseed under cage condition of subtropical climate in inner terai, Chitwan, Nepal.

\section{Materials and Methods}

An experiment was conducted at Jutpani VDC, Chitwan district Nepal during October 2012 to February 2013. The plot size of each treatment was $3 \mathrm{~m}$ x $5 \mathrm{~m}\left(15 \mathrm{~m}^{2}\right)$ separated by $0.5 \mathrm{~m}$ distance between plots and $1 \mathrm{~m}$ between replications. Rapeseed variety Pragati was sown on 03 November 2012 with all the agronomical practices followed. The seeds were sown at 3-4 cm depth of soil @ 6 $\mathrm{kg} / \mathrm{ha}$ in well prepared field maintaining $20 \mathrm{~cm} \times 5 \mathrm{~cm}$ spacing between row to row and plant to plant, respectively. Native honeybee, Apis cerana F. and exotic honeybee, Apis mellifera L. plots were covered with mosquito nets $(5 \mathrm{~m} \times 3 \mathrm{~m} \times 2.5 \mathrm{~m}$ size $)$. The caged were erected on field plots when the crop reached at $5-10 \%$ flowering stage. Thereafter, already produced four colonies of Apis cerana F. and four colonies of Apis mellifera L. with fully covered two- frame hives with a queen, and containing broods and 
eggs of each species were placed separately inside cage at 29 DAS on experiment field.

Observation on foraging behaviors of Apis cerana F. and Apis mellifera L., such as commencement and cessation, number of plants and flowers visits/minute, number of bees in per meter square area per minute under caged condition were recorded. These records were taken four times at 10:00 am, 12:00 noon, 2:00 pm and 4:00 pm of the day at different rapeseed flowering stages. Number of outgoing and incoming bees with pollen/without pollen of Apis cerana F. and Apis mellifera L. were also recorded under caged condition. These records were taken five times at 8:00 am, 10:00 am, 12:00 noon, 2:00 pm and 4:00 pm of the day at different rapeseed flowering stages.

\section{Results and Discussions}

Table 1 clearly shows that Apis cerana $\mathrm{F}$. foraged extra 42 minute per day on rapeseed flower as compared to Apis mellifera L. and numbers of bees per meter square per minute of both honeybees species were recorded highest at 2:00 pm and lowest number at 4:00 pm (Fig. 1). At morning and late hour of the day number of Apis cerana F. was recorded higher than number of Apis mellifera L. whereas at mid-day hour number of A. mellifera L. recorded higher. Early initiation of foraging by Apis cerana F. than Apis mellifera L. also reported by Devkota (2000) as Apis cerana at 8:40 am and Apis mellifera at 9:07 am. This was in comparison to foraging activities of Apis cerana $\mathrm{F}$. starting early in the morning at 06.14 am and ceasing late in the evening at $17.28 \mathrm{pm}$ (Singh, 2008). Dhakal (2003) reported 6.52 am and 6.59 am as initiation of foraging activities of Apis cerana and Apis mellifera on rapeseed in Chitwan. It was due to foggy condition and low temperature during rapeseed cropping season. This result clears that under slightly unfavourable environmental condition the activity of Apis mellifera L. is decreases whereas but Apis cerana F. does not. It shows that Apis cerana F. can forage flower even slightly unfavourable environmental condition. In a study it showed that the number of bees per meter ranged between 4.0-12.0 and 2.6-10.2 in the case of Apis mellifera L. and Apis cerana F. respectively (Verma, 1990). Similar result were reported as more number of Apis mellifera L. at noon and least at 9:00 am and 15:00 pm as compared to Apis cerana F. (Kasina, 2009) .

Table 1: Different parameters of foraging behavior of Apis cerana F. and Apis mellifera L. on rapeseed under caged condition in Chitwan, 2012/013*

\begin{tabular}{|c|c|c|c|}
\hline Parameters & & Apis cerana $\mathrm{F}$. & Apis mellifera $\mathrm{L}$. \\
\hline Initiation of foraging time & & $7: 51 \mathrm{am}$ & $8: 18 \mathrm{am}$ \\
\hline Cessation of foraging time & & $5: 41 \mathrm{pm}$ & $5: 26 \mathrm{pm}$ \\
\hline \multirow[t]{4}{*}{ Number of bees per meter square per minute } & $10: 00 \mathrm{am}$ & $8.667 \mathrm{~b}$ & $7.668 \mathrm{c}$ \\
\hline & $12: 00 \mathrm{pm}$ & $10.67 \mathrm{ab}$ & $11.00 \mathrm{~b}$ \\
\hline & $2: 00 \mathrm{pm}$ & $12.83 \mathrm{a}$ & $15.17 \mathrm{a}$ \\
\hline & $4: 00 \mathrm{pm}$ & $5.500 \mathrm{c}$ & $5.000 \mathrm{~d}$ \\
\hline
\end{tabular}

* Means followed by the same letter in each column are not significantly different by DMRT at $\leq 0.05$ percent level.

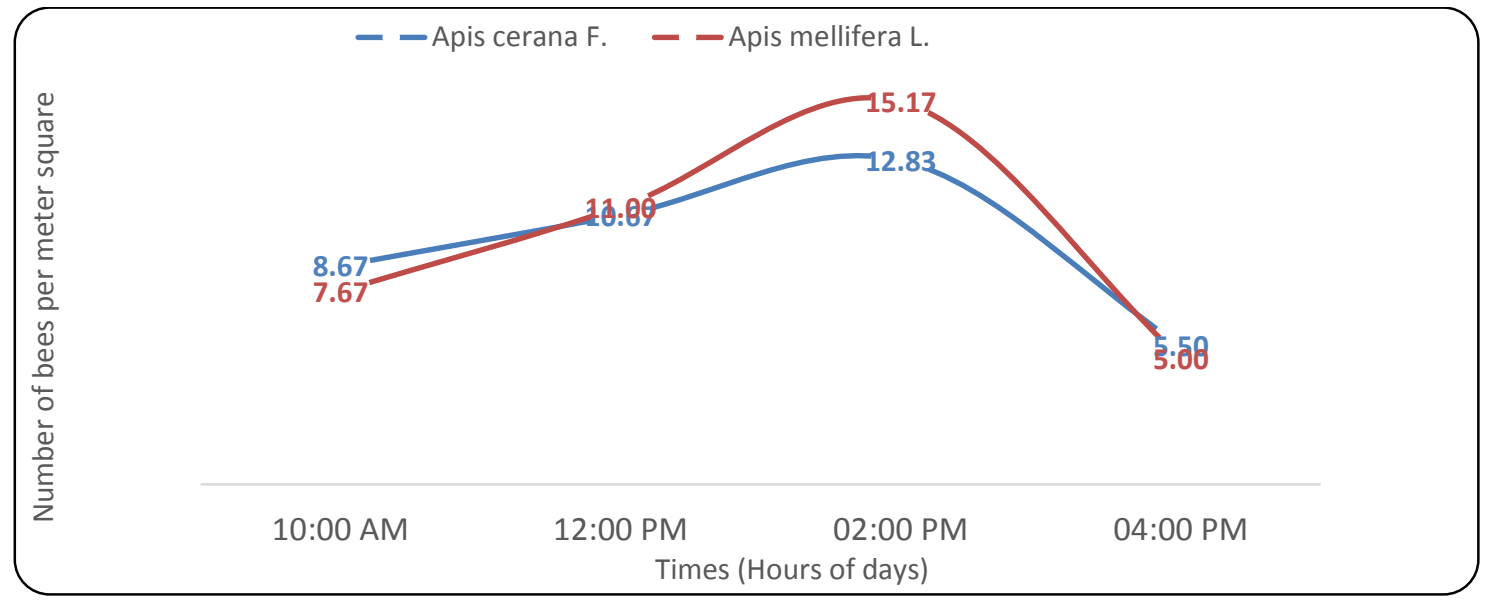

Fig. 1: Number of Apis cerana F. and Apis mellifera L. in per meter square area under caged condition in Jutpani VDC, 2012/2013 
Table 2: In and out from hives with pollen: nectar ratio by Apis cerana F. and Apis mellifera L. on rapeseed under caged condition in Chitwan, $2012 / 013$

\begin{tabular}{llll}
\hline Parameters & Time & Apis cerana $\mathbf{F}$. & Apis mellifera $\mathbf{L}$. \\
\hline In into hives & $8: 00 \mathrm{am}$ & $0.5 \mathrm{~d}$ & $0 \mathrm{~d}$ \\
$10: 00 \mathrm{am}$ & $12.16 \mathrm{c}$ & $17 \mathrm{c}$ \\
$12: 00 \mathrm{pm}$ & $21.16 \mathrm{~b}$ & $36 \mathrm{~b}$ \\
$2: 00 \mathrm{pm}$ & $43.66 \mathrm{a}$ & $44.33 \mathrm{a}$ \\
& $4: 00 \mathrm{pm}$ & $13 \mathrm{c}$ & $16.5 \mathrm{c}$ \\
Out from hives & $8: 00 \mathrm{am}$ & $0.66 \mathrm{e}$ & $0 \mathrm{e}$ \\
& $10: 00 \mathrm{am}$ & $8.83 \mathrm{~d}$ & $11.66 \mathrm{~d}$ \\
& $12: 00 \mathrm{pm}$ & $23.5 \mathrm{~b}$ & $33.66 \mathrm{~b}$ \\
& $2: 00 \mathrm{pm}$ & $48.16 \mathrm{a}$ & $49.66 \mathrm{a}$ \\
Pollen: nectar collectors ratio & $4: 00 \mathrm{pm}$ & $16.5 \mathrm{c}$ & $24 \mathrm{c}$ \\
& $10: 00 \mathrm{am}$ & $1.16: 1$ & $1.22: 1$ \\
$12: 00 \mathrm{pm}$ & $0.82: 1$ & $0.85: 1$ \\
& $2: 00 \mathrm{pm}$ & $0.51: 1$ & $0.58: 1$ \\
& $4: 00 \mathrm{pm}$ & $0.30: 1$ & $0.41: 1$ \\
\hline
\end{tabular}

* Means followed by the same letter in each column are not significantly different by DMRT at $\leq 0.05$ percent level.

Table 2 shows that the number of Apis cerana F. and Apis mellifera L. in and out of hives was significant at different times of the day. At 8:00 am, no movement of Apis mellifera L. was observed but there were some Apis cerana F. in rapeseed fields. The highest in-out were observed at 2:00 pm on both species as Apis mellifera L. 44.33 bees entered into hives and 49.66 bees went out of hives, whereas lower number of Apis cerana F. 43.66 bees entered into hives and 48.16 bees were out of hives. The foraging activity of Apis cerana F. was observed at 11:00 to 13:00 hrs and then a steady decline was recorded which abruptly decreased between 17:00 to 18:00 hrs. However, in the case of Apis mellifera L., the increase was steady and reached its peak between 1300 to 1500 hrs (Joshi and Joshi, 2010). Similarly, higher pollen: nectar ratio was recorded at morning hours of the day in both species. Apis mellifera L. had more pollen nectar ratio in all over the day hours as compare to Apis cerana F. A. mellifera collect 1.22:1 and 0.41:1 pollen nectar ratio at 10:00 am and 4:00 am whereas at same hours Apis cerana collect 1.16:1 and 0.30:1 pollen nectar ratio. This result indicated that Apis cerana F. were more attracted to nectar, whereas Apis mellifera L. were more attracted to pollen collection throughout the day in rapeseed crop. Higher pollen: nectar ratio was also reported by Partap et al. (2000) in Apis cerana F. that pollen collection excelled nectar collection throughout the day, whereas for Apis mellifera L., $\mathrm{P}>\mathrm{N}$ at $10.00 \mathrm{~h}, \mathrm{~N}=\mathrm{P}$ at 12.00 $\mathrm{h}$ and $\mathrm{N}>\mathrm{P}$ at $14.00 \mathrm{~h}$. Similarly, Devkota (2000) reported higher amount of pollen collection 1:054 and 1:3.33 by Apis cerana $F$. and $1: 0.33$ and 1.1 .01 by Apis mellifera L. at 10:00 am and 4:00 pm.

Similarly, Apis cerana F. also had greater flower and plant visiting efficiency as compared to Apis mellifera L. under caged condition. The average number of flowers and plants visited by Apis cerana F. were 24.33 and 15.50 flower per minute and 14.17 and 9.333 plants per minute at 2:00 pm and 10:00 am of day hours. But Apis mellifera L. visited fewer flowers and plant number at same day hours, i.e. 19.00 and 12.67 flower numbers per minute and 12.83 and 7.50 plants number per minute. It showed that Apis cerana F. visited higher number of flowers and plants and hence more efficient pollinator (Fig. 2). The highest number of plants and flowers were visited by both species at 2:00 pm followed by 12:00 pm and 4:00 pm, while the lowest number visited at 10:00 am. Similar result was also presented on rapeseed as Apis cerana F. visited 18.0, 19.8 and 14.2 flowers, and Apis mellifera L. visited 14.2, 15.4 and 14.5 flower at 9:00, 12:00 and 15:00, respectively (Dhakal, 2003). Longer duration was given by Apis mellifera on apple flower as reported by Verma and Dutta (1986) and Desh and Rana (1994) on rapeseed flower. Desh and Rana (1994) on rapeseed reported that these species spent maximum time per flower at $09.00 \mathrm{~h}$ than at $12.00 \mathrm{~h}$ and $15.00 \mathrm{~h}$. In another experiments, it was reported that Apis cerana F. foraged higher number of broccoli flowers 11.39 and 12.11 flowers per minute as compared to Apis mellifera L. 9.03 and 10.89 flowers per minute under caged and open conditions, respectively (Devkota and Thapa, 2005). 
Table 3: Flowers and plant visited per minute by Apis cerana F. and Apis mellifera L. on rapeseed under caged condition in Jutpani VDC, Chitwan, 2012/013

\begin{tabular}{llll}
\hline Parameters & Time & Apis cerana $\mathrm{F}$. & Apis mellifera $\mathrm{L}$. \\
\hline Plant visited per minute & $10: 00 \mathrm{am}$ & $9.333 \mathrm{~b}$ & $12.83 \mathrm{~b}$ \\
& $12: 00 \mathrm{pm}$ & $13.00 \mathrm{a}$ & $10.17 \mathrm{~b}$ \\
& $2: 00 \mathrm{pm}$ & $14.17 \mathrm{a}$ & $8.167 \mathrm{a}$ \\
& $4: 00 \mathrm{pm}$ & $9.667 \mathrm{~b}$ & $7.500 \mathrm{~b}$ \\
Flower visited per Minute & $10: 00 \mathrm{am}$ & $15.50 \mathrm{c}$ & $19.00 \mathrm{~b}$ \\
& $12: 00 \mathrm{pm}$ & $21.00 \mathrm{~b}$ & $16.67 \mathrm{ab}$ \\
& $2: 00 \mathrm{pm}$ & $24.33 \mathrm{a}$ & $13.33 \mathrm{a}$ \\
& $4: 00 \mathrm{pm}$ & $17.17 \mathrm{c}$ & $12.67 \mathrm{~b}$
\end{tabular}

* Means followed by the same letter in each column are not significantly different by DMRT at $\leq 0.05$ percent level.

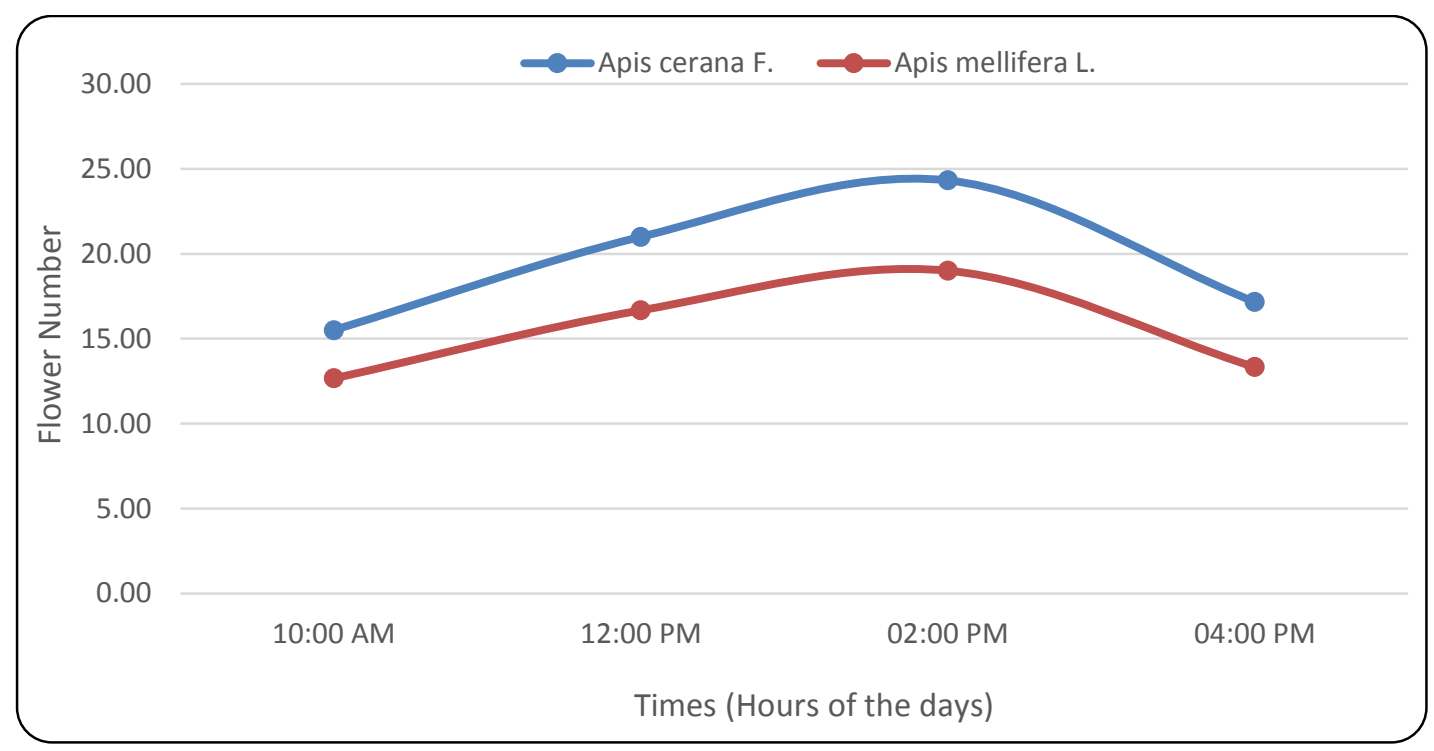

Fig. 2. Number of flowers visited per minute by Apis cerana F. and Apis mellifera L. at different times of the day under caged condition in Jutpani VDC, 2012/013

\section{Conclusions}

It is concluded that Apis cerana F. foraged more extra time per day on rapeseed flower as compared to Apis mellifera L. The peak foraging hours for both bee species were recorded around 12:00 noon to 14:00 pm. The Apis cerana F. visited higher number of flowers and plants as compared to Apis mellifera L. under cage condition and hence, Apis cerana F. is efficient pollinators as compared to Apis mellifera $\mathrm{L}$.

\section{References}

Desh R and Rana VK (1994) Time spent by Apis mellifera L. and Apis cerana F. foragers on rapeseed bloom. Journal of Entomology Research 18: 361-387.

Devkota FR (2000) Comparative pollination behaviour of Apis cerana F. and Apis mellifera L. on broccoli and their impact on seed production under Chitwan conditions. M. Sc. In Entomology thesis. TU. IAAS Rampur, Chitwan, Nepal. 67 p.
Devkota FR and Thapa RB (2005) Foraging preference of Apis cerana $\mathrm{F}$. and Apis mellifera $\mathrm{L}$. to broccoli under caged and open conditions in Chitwan. Institute of Agriculture and Animal Science 26: 167-168.

Dhakal GC (2003) A comparative study of Apis cerana F. and Apis mellifera L. on pollination of Brassica campestris Var. toria and Fagopyrum esculentum M. at Rampur, Chitwan. M. Sc. In Entomology Thesis TU. IAAS Rampur, Chitwan, Nepal. 76 p.

Free JB (1970) Insect pollination of crop plants. Academic Press, New York, USA. 332 p.

Gilbert FS (1980) Flower visiting by hoverflies (Syrphidae). Annual Revision of Ecological System 6: 139-170.

Inouye D (1980) The effect of proboscis and corolla tube lengths on patterns and rates of flower visitation by bumble bees. Oecologia 45: 197-201. DOI: 10.1007/BF00346460 
Joshi NC and Joshi PC (2010) Foraging behavior of Apis spp. on apple flowers in a subtropical environment. New York Science Journal 3: 71-76.

Kasina M, Kraemer M, Martius C and Wittmann D (2009) Diversity and activity density of bees visiting crop flowers in Kakamega, western Kenya. Journal of Apicultural Research 48: 134-139. DOI: 10.3896/IBRA.1.48.2.08

NARC (2008) Introduction of trained bees, Apis mellifera L. for quality seed and higher seed on mustard, Brassica campestris Var. toria in Nepalese condition. Annual Technical Report 2006-2007. Entomology Division, Nepal Agriculture Research Council. Khumaltar, Lalitpur, Nepal. pp. 27-32.

Partap U and Partap T (1997) Managed crop pollination. The missing dimension of mountain crop productivity. Discussion paper series No. MFS 97/1, ICIMOD, Kathmandu, Nepal. 26 p.

Partap U, Sukla AN and Verma LR (2000) Comparative foraging behavior of Apis cerana himalaya in pollinating peach and plum flower in Kathmandu Valley, Nepal. In: M. Matska, L. R. Verma, S. Wongsiri, K. K. Shrestha and U. Partap (eds.). Asian Bees and Beekeeping-Progress of Research and Development. Proceeding of Fourth Asian Apicultural Association International Conference, Kathmandu. March 23-28, 1998. Oxford and IBH Publication Company Private Limited, India. 283 p.
Rao GM (1991) Studies on the floral biology and pollination requirements of scented Methi (Trigonella corniculata $\mathrm{L}$.) Indian Bee Journal 53: 39-43.

Rao GM and Suryanarayana MC (1990) Studies on the foraging behavior of honeybees and its effect on the seed yield in Niger. Indian Bee Journal 52: 31-33.

Robinson WE and Morse RA (1989) The value of honeybees as pollinators of US crops. American Bee Journal 129: 477487.

Singh J, Agarwal, OP, Mishra, RC (2006) Foraging rates of different Apis species visiting parental lines of Brassica napus L. Zoos' print journal 21: 2226-2227. DOI: 10.11609/JoTT.ZPJ.1315.2226-7

Singh MM (2008) Foraging behavior of the Himalayan honeybee (Apis cerana F.) on flowers of Fagopyrum esculentum M. and its impact on grain quality and yield. Ecoprint 15: 37 46.

Verma LR (1990) Beekeeping in integrated mountain development: economic and scientific perspectives. ICIMOD senior fellowship Series, No. 4 Oxford and IBH Publishing Company. Private. Limited, New Delhi, India. $387 \mathrm{p}$.

Verma LR, and Dutta PC (1986) Foraging behaviour of Apis cerana indicia and Apis mellifera in pollinating apple flowers. Journal Apiculture Research 25: 197-201. 